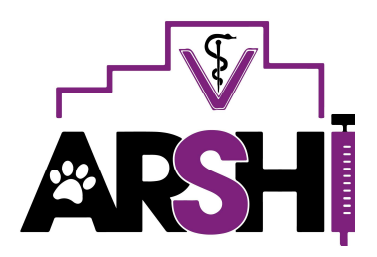

\title{
Kasus swimmer syndrome pada seekor anak kucing
}

\author{
Arief Purwo Mihardi ${ }^{*}$, Kaela Natania ${ }^{2}$, Klasta J. Sanjaya ${ }^{2}$, Eka D. Wulandari ${ }^{3}$, Arni Suryani ${ }^{3}$ \\ ${ }^{1}$ Departemen Klinik, Reproduksi, dan Patologi, Fakultas Kedokteran Hewan, Institut Pertanian Bogor, Bogor. \\ ${ }^{2}$ Program Pendidikan Profesi Dokter Hewan, Fakultas Kedokteran Hewan, Institut Pertanian Bogor, Bogor. \\ ${ }^{3}$ Dokter Hewan Praktisi, Klinik Hewan Pet Vet, Jakarta
}

\begin{abstract}
ABSTRAK: Swimmer syndrome merupakan kondisi gangguan muskuloskeletal kongenital yang dapat terjadi pada anak kucing yang menyebabkan kaki menjadi terbuka ke arah lateral dan menyebabkan postur seperti katak. Seekor anak kucing persia betina bernama NN berusia 2 minggu dibawa ke Klinik Hewan Pet Vet menunjukkan gejala klinis mengalami kesulitan berjalan dengan gerakan seperti berenang. Pemeriksaan fisik menunjukkan kucing memiliki flat chest sehingga pernafasan terlihat dangkal dan cepat. Anak kucing didiagnosa mengalami swimmer syndrome. Terapi yang dilakukan terhadap anak kucing yaitu dengan memakaikan alat penahan pada bagian dada yang berbentuk setengah lingkaran. Alat ini diikatkan melingkari bagian dada dan dikenakan setiap hari. Perkembangan yang cukup baik ditunjukkan setelah 7 hari, dimana NN mulai dapat mengangkat tubuh dan dapat berjalan secara normal. Penggunaan alat bantu sebagai terapi pada kasus ini tetap diteruskan karena pembentukan tulang bagian dada yang belum sempurna.
\end{abstract}

\section{Kata kunci:}

Kucing, flat chest, muskoloskeletal, swimmer syndrome

\section{- PENDAHULUAN}

Swimmer syndrome merupakan kondisi kongenital pada anak kucing yang menyebabkan kaki (terutama kaki belakang) menjadi terbuka kearah lateral dan postur seperti katak. Anak kucing yang menderita swimmer syndrome akan kesulitan untuk berjalan ataupun berdiri yang terjadi pada usia 15-21 hari dan dapat diobati jika segera ditangani (Dumon 2005). Kondisi ini menyebabkan kapasitas gerakan fisik tertunda, kelainan bagian panggul dan dada (Verhoeven et al. 2006).

Anak kucing secara normal mampu berdiri dan berjalan pada usia 10- 15 hari pascalahir (Hoskins 2001). Menurut para peneliti, patogenesa penyakit ini masih belum jelas. Faktor keturunan, lingkungan, gizi, saraf, dan ortopedi merupakan hal yang mungkin menjadi penyebab swimmer syndrome (Yardimci et al. 2009). Gejala klinis dapat dilihat sejak awal mulai dari minggu pertama. Diagnosa definitif dapat dibuat berdasarkan sejarah, gejala klinis, dan pemeriksaan radiografi (Burger et al. 2007). Laporan kasus swimmer syndrome di Indonesia sulit didapatkan. Tulisan ini melaporkan penanganan pada kasus ini untuk pertama di Indonesia.

\section{- KASUS}

Sinyalemen: Seekor kucing betina bernama NN ras persia berumur 2 minggu dan rambut berwarna putih abu-abu. Anamnesa: Pemilik membawa kucing ke klinik dengan keluhan lemas dan bentuk tubuhnya berbeda dengan anak kucing lainnya. Gejala klinis: Kucing mengalami kesulitan berjalan dengan gerakan seperti berenang, memiliki flat chest dimana bagian ada menjadi rata sehingga gerakan pernafasan terlihat dangkal dan cepat (Gambar 1A). Diagnosa: swimmer syndrome. Prognosa: Fausta. Terapi: fisioterapi dengan memakaikan alat bantu.

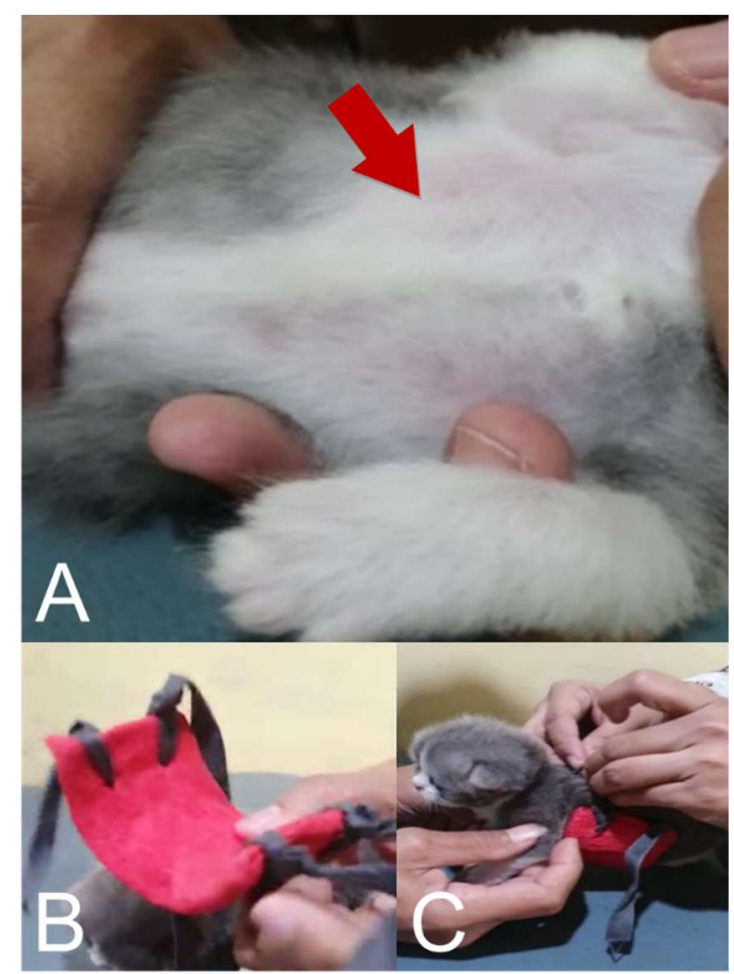

Gambar 1 Flat chest pada kucing NN dada datar/rata, (B) alat bantu penopang dada, dan (C) pemasangan penopang pada kucing.

Diterima: 02-03-2021 | Direvisi: 19-04-2021 | Disetujui: 21-04-2021 (C) 2021 CC-BY-SA. Ini adalah artikel Open Access yang didistribusikan berdasarkan ketentuan dari Creative Commons Attribution ShareAlike 4.0 International License (https://creativecommons.org/licenses/by-sa/4.0/). 


\section{- HASIL DAN PEMBAHASAN}

Kucing secara konstan menunjukkan abduksi karena hiperfleksi dari artikulasi coxofemoral bilateral, hiperfleksi sendi tibial-patellofemoral dan persendian tibiotarsal. Ketika dada terpengaruh, kucing yang baru lahir menunjukkan ketidakmampuan mendukung kerangka apendikular, menyebabkan kompresi dada, abdomen, dan pelvis secara dorsoventral. Hal ini ditunjukkan dengan perilaku seperti bersepeda lateral dan defleksi anggota tubuh kaudolateral, yang mencirikan gerakan seperti berenang (swimmers syndrome) (Yardimci et al. 2009).

Ketidakmampuan kucing untuk mengangkat tubuh secara efektif menyebabkan toraks menjadi rata (flat chest), lesi kulit, regurgitasi susu, sianosis, dispnea, dan pneumonia aspirasi (Dumon 2005). Hipotesis dapat menjadi penyebab penyakit ini, termasuk faktor keturunan, lingkungan, diet yang tidak seimbang (protein berlebihan), kelainan metabolisme, masalah perkembangan, obesitas, dan neurological disorder (myelinasi dari motor neuron perifer yang terlambat atau alterasi fungsi pada neuromuscular) (Forsber 2010).

Sebuah penelitian di United Kingdom (UK) menunjukkan bahwa 3-4\% anak kucing breed Burmese mengalami swimmer syndrome. Tahun 2017 di Swedia dilaporkan prevalensi penyakit pada breed Bengal 6\% lebih tinggi dibandingkan dengan domestic short hair (DSH), dengan 44\% breeder mengalami malformasi pada 1-3 litter di usia 4 minggu. Kematian pada anak kucing sebesar $50-60 \%$ pada kasus ini (Charlessworth et al. 2012).

Kasus swimmer syndrome sangat jarang terjadi pada kucing, terutama pada satu individu saja. Syndrome ini biasanya terjadi pada kucing dengan kelahiran yang sama (satu induk) (Cardili et.al 2013). Kasus ini tidak memiliki predisposisi ras pada kucing. Beberapa laporan kasus juga menunjukkan bahwa kucing dengan peranakan kecil lebih berpotensi terkena syndrome ini daripada kucing dengan peranakan yang besar (Cardili et al. 2013).

\section{- PENANGANAN DAN PENGOBATAN}

Penanganan swimmer syndrome dengan pembuatan alat bantu penahan berbentuk setengah lingkaran fleksibel yang dapat menahan bagian dada agar tidak tertekan dengan lantai dan mendukung pembentukan dada. Alat diikatkan melingkari dada dan dikenakan setiap hari (Gambar 1B dan C). Anak kucing mengalami perkembangan bagian dada setelah seminggu terapi. Kucing NN mampu mengangkat tubuhnya sendiri dan mulai berjalan, namun karena pembentukan dada belum sempurna, maka alat terus digunakan dengan ukuran yang disesuaikan bentuk dan besar badan anak kucing.

Pengobatan swimmer syndrome berupa kelemahan otot tubuh bagian kaki belakang dilakukan menggunakan medical tape yang dipasang pada kaki belakang. Tujuan pemasangan medical tape adalah untuk mendekatkan kedua kaki belakang dan mengoreksi posisi kaki agar berada di bawah tubuh sebagai alat pendukung (Verhoeven et al. 2006).
Terapi fisik pada kaki yang mengalami kelemahan juga dapat dilakukan sebagai pengobatan. Terapi fisik dilakukan dengan melepas terlebih dahulu alat bantu yang digunakan. Kemudian dilakukan serangkaian gerakan menarik kaki, dan menekuk sendi serta meletakkan kaki di bawah tubuh. Terapi ini dilakukan berulang kali untuk merangsang kucing agar menggunakan kaki dengan benar. Mainan kucing dapat digunakan sebagai alat untuk menarik perhatian kucing agar bergerak dan melatih otot kaki (Kim et al. 2013). Gerakan bersepeda juga dapat dilakukan dengan memegang kucing secara terlentang kaki kucing digerakkan seperti sedang mengayuh sepeda. Pemijatan juga dapat dilakukan untuk membantu melancarkan peredaran darah pada kaki yang mengalami kelemahan otot (Cardilli et al. 2013).

\section{- SIMPULAN}

Kucing Persia berusia 2 minggu mengalami swimmer syndrome dan mendapat pengobatan dengan pemasangan alat bantu penahan dada. Kucing sudah menunjukan perkembangan yang baik setelah selama satu minggu terapi sehingga penggunaan alat penopang dilanjutkan.

\section{- INFORMASI PENULIS}

\section{Penulis Korespondensi}

*AP: mihardi.ap@gmail.com

Departemen Klinik, Reproduksi dan Patologi,

Fakultas Kedokteran Hewan, Institut Pertanian Bogor

Jl. Agatis, Kampus IPB Dramaga Bogor 16680

\section{- PUSTAKA ACUAN}

Cardilli DJ, João CF, Voorwald FA, Tinucci-Costa M, Toniollo GH. 2016. Swimmer syndrome affecting anentire litter of kittens. Arquivo Brasileiro de Medicina Veterinária e Zootecnia. 65(3): 705709.

Charlesworth, Timothy M, Sturgess CP. 2012. Increased incidence of thoracic wall deformities in related Bengal kittens. Journal of Feline Medicine and Surgery 14(6): 365-368.

Dumon C. 2005. The musculoskeletal system: the first 15 days. Neonatology and Pediatrics Canine and Feline. 01: 126-151.

Forsberg CL. 2010. Abnormalities in pregnancy, parturition, and the periparturient period. In: Ettinger SJ, Feldman EC (Eds) Textbook of Veterinary Internal Medicine. 7ed. St Louis, Missouri (US): Elsevier Saunders.

Hoskins JD. 2001. Swimmer puppies and kittens. Veterinary Pediatrics. 3: 419-420.

Kim SA, Na KJ, Cho JK, Shin NS. 2013. Home-care treatment of swimmer syndrome in a miniature schnauzer dog. Canine Veterinary Journal. 54(9): 869-872.

Ramos RM, Atallah FA, Luz MJ, Scheffer JP, Hyppolito WC, Amaral LG, Silva RS, Lacerda A, Oliveira A. 2013. Síndrome do cão nadador: estudo retrospectivo de 26 casos. Revista Brasileira de Medicina Veterinária. 35(1): 96-100.

Verhoeven G, Rooster H, Risselada M. Swimmer syndrome in a Devon rex kitten and an English bulldog puppy. Journal Small Animal Practice. 2006 47: 615-619.

Yardimci C, Ozak A, Nisbet HO. 2009. Swimming syndrome in two Labrador puppies. Kafkas Universitesi Veteriner Fakultesi Dergisi. 15(4):637-640. 